\title{
Financial and Nonfinancial Performance of Micro Enterprises in Selected Area in Malaysia
}

\author{
Nurul Nadiah Ahmad \\ Department of Accounting, Universiti Tenaga Nasional, Malaysia
}

\begin{abstract}
Malaysian economic growth is greatly contributed by the micro enterprises as the highest establishment among Small and Medium Enterprises (SMEs). Thus, this study aims to measure their performance in term of financial and nonfinancial aspects. By using sampling methods include cluster, simple random and convenience sampling; a total of 200 sets of the questionnaire have been distributed to micro enterprises in service sector equally in Malaysia area includes Wilayah Persekutuan (WP) Kuala Lumpur, Selangor, Kedah and Kelantan. The result of this study shows that most of the selected micro enterprises have good financial and nonfinancial performance. This study is valuable for practitioners such owners/managers which will help them to make a better strategy in order to improve and enhance their enterprises.
\end{abstract}

Keywords: SME, micro enterprises, performance, financial and nonfinancial

\section{Introduction}

Small and Medium Enterprises (SMEs) played a vital role in the economic growth of the world. Directly, SMEs had provided a high quality of products/services in order to compete in a competitive environment. In addition, SMEs had also offered the opportunity of job improvement in order to enhance their performance (Farhan \& Nur Naha, 2011; Che Zuriana \& Rapiah, 2011). Besides that, Nurazree and Mohd Faiz (2013), Majidah and Grace (2011) stated that SMEs had become an important element in the economic development of most countries include both developed and developing countries. As progressively more of the SMEs of those countries involve in international business like export and import transactions to improve the country economic condition. On the other hand, SMEs had the capability of making quick adjudication, working with less capital, but more intense labor, as well as having a low cost of management that led to cheap production cost (Canan, Hidayet, Yasemen, Perihan \& Hakan, 2008). Thus, SME was the most important enterprise of a country that contributed toward its Gross Domestic Product (GDP) of the country.

There is no consensus regarding the definition of SMEs. SMEs consist of three categories which are micro, small and medium enterprises (SME Corporation (Corp), 2014). According to Department of Statistics, Malaysia (2011), total numbers of the SMEs establishment were 645,136. While, based on their sizes that consist of micro enterprises were 496,458 establishments, small were 128,787 enterprises and the rest was medium enterprises with 19,891 establishments. Thus, micro enterprises had major establishments in the total of SMEs. Furthermore, SMEs had been separated into several sectors including manufacturing, services and other sectors which consisted of mining and quarrying sector, construction sector and agriculture sector (SME Corp, 2014).

Apart from that, almost economies of all countries were influenced by the performance of SMEs (Nurazree \& Mohd Faiz, 2013). Performances of SMEs were determined by their capabilities to survive in a competitive market and also sustain for a long term (Krishna, Annie, Caroline, Chang,
Jonathan \& Tan, 2012). There are two types of performance that could be measured by SMEs which are financial and non-financial performance (Mohd Amy, Chee \& Mohamad Izham, 2013). Financial performance was a subjective measure of how excellent enterprises could utilize their assets from their primary enterprise activities and generated future cash flow to the entity (Annastazia \& Robert, 2014; Nyangoma 2012). For examples, profit, sales and cash flow. Meanwhile, according to Dikolli (2010), non-financial performance was a measurement to evaluate the quality of the enterprise that not be stated in monetary units. For instance, it was embraced of employee satisfaction, customer satisfaction and product development.

Some of the SME was facing troubles and difficulties, especially in surviving and sustaining the enterprise in a competitive environment (Nyanga, Zirima, Mupani, Chifamba \& Mashavira, 2013). According to Wong, Kuek and Ong (2013), most of the SMEs could not sustain themselves over the long-term period due to poor performance. In addition, some of the SMEs could not survive the first five years of their establishments in the market due to failure in planning excellent strategies in order to sustain the enterprise (Monge-González \& TorresCarballo, 2015). Moreover, Mbugua, Agnes and Ondabu (2014) explained that SMEs performed poorly, added with poor management that directly caused the enterprises failed to grow. SMEs were facing high competition not only from their peers but also from large corporations (Mbugua et al., 2014; Awa, Ojiabo \& Emecheta, 2012). Moreover, many new enterprises were established in Malaysia selling commodity products which were similar products within the market. This situation led them to fail to sustain or enlarge their enterprises.

\section{Literature Reviews}

\subsection{Small Medium Enterprise}

SMEs consist of three categories which are micro, small and medium. For each category, SMEs had been classified based on number of labor force, size of company, income level and

\section{Volume 6 Issue 7, July 2017}




\section{International Journal of Science and Research (IJSR) \\ ISSN (Online): 2319-7064}

Index Copernicus Value (2015): 78.96 | Impact Factor (2015): 6.391

capital requirement (Khrystyna, Melina \& Rita, 2010).

Table 1: Definition of SME in Malaysia

\begin{tabular}{|c|c|c|}
\hline $\begin{array}{l}\text { Categories } \\
\text { / Sectors }\end{array}$ & Manufacturing & $\begin{array}{l}\text { Services and Other } \\
\text { Sectors }\end{array}$ \\
\hline Medium & $\begin{array}{c}\text { Sales turnover : } \\
\text { RM15 million-RM50 million } \\
\text { Employees: } 75-200\end{array}$ & $\begin{array}{c}\text { Sales turnover : } \\
\text { RM3 million-RM20 } \\
\text { million } \\
\text { Employees : } 30-75\end{array}$ \\
\hline Small & $\begin{array}{c}\text { Sales turnover : } \\
\text { RM300,000 - RM15 million } \\
\text { Employees : } 5-75\end{array}$ & $\begin{array}{c}\text { Sales turnover : } \\
\text { RM300,000 - RM3 } \\
\text { million } \\
\text { Employees : } 5-30\end{array}$ \\
\hline Micro & \multicolumn{2}{|c|}{$\begin{array}{c}\text { Sales turnover }:<\text { RM300,000 } \\
\text { Employees }:<5\end{array}$} \\
\hline
\end{tabular}

\subsection{Financial Performance}

Annastazia and Robert (2014) defined financial performance as the process to interpret of business financial statements. Moreover, Nyangoma (2012) stated that the capability of the enterprise to create wealth during start-up of the enterprise and survive or maintain in the market show positive financial performance. Generally, financial performance is a subjective measure of how excellent enterprises can utilize their assets from their primary enterprise activities and generate future cash inflow to the entity. It show an overall enterprise financial situation or condition over a specific period of time and can be used to compare with other enterprise within the same industry in order to evaluate the performance.

There are numerous measurements of financial performance includes profitability, size and growth. While, this study uses profit, sale and cash flow to measure the financial performance of micro enterprises as this study was replicated from previous studies (Mashenene, Macha \& Donge, 2014; Annastazia \& Robert, 2014; Tundui, 2012; Nyangoma, 2012). Tundui (2012) used sales volume to measure the financial performance of SMEs. As the higher sales volume of the enterprise, it indicates higher profit that enterprise obtained and the enterprise has a good performance. Furthermore, the stable profit and growth of the enterprise shows that it has a good performance (Annastazia \& Robert, 2014; Nyangoma, 2012). On the other hand, it is easier for the enterprise to get this kind of financial information if the enterprise keep and maintain the record properly.

\subsection{Non-financial Performance}

Dikolli (2010) defined non-financial performance is any measurement of quantitative information about the enterprise that cannot measure in a monetary unit. Instead of accessing quantitative information in monetary value, enterprises need to evaluate qualitative evidence as well, in order to justify whether their performance are satisfied or not. Recently, many enterprises have seen qualitative information as a vital part in improving their performance. Therefore, non-financial performance measures are expected to be the leading indicators of future performance measurement. Common examples of non-financial performance include measurement of employee or customer satisfaction, market expansion or growth and the number of new products produced.
Measurement for non-financial performance of micro enterprises in term of their customer, employee and product development as this study was replicated from previous studies (Daniel \& Okibo, 2014; Christopher \& David, 2003). According to Christopher and David (2003), non-financial performance of the enterprise can be measured by customer loyalty and employee satisfaction that ultimately affected the profitability of the enterprise. As there are more customers and employees loyalty in the enterprise due to satisfaction with the products/services provided, then the enterprise has a good performance. Meanwhile, Daniel and Okibo (2014) used growth in employees, markets and product development in measuring non-financial performance of the enterprise. If the enterprise attempts to explore into new market or produce new products/services, then it will increase its performance.

\section{Methodology}

The population of this study is micro enterprises in service sector in Malaysia. The main reason micro enterprise is selected as population of this study because it has the highest establishments in SMEs (SME Corp, 2014).

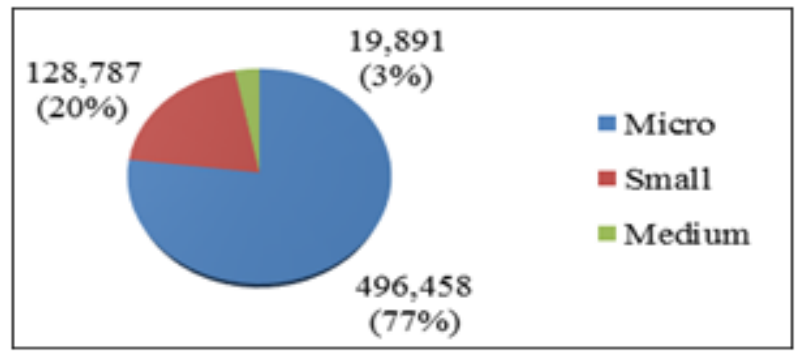

Figure 1: Number of SMEs Establishment Based on Size

Figure 1 shows number of SMEs establishments in year 2011 based on size where the majority of establishment is coming from the micro enterprises which is $77 \%$. Whereas, the number of establishments for small and medium enterprises are $20 \%$ and $3 \%$ of total SMEs respectively. Therefore, due to majority establishments, micro enterprises are selected as population.

Table 2: Number of Micro Enterprises Establishment by

\begin{tabular}{|l|c|}
\hline SECTOR & Mector \\
\hline & Number of establishment \\
\hline Manufacturing & 21,619 \\
\hline Service & 462,420 \\
\hline Agriculture & 3,775 \\
\hline Construction & 8,587 \\
\hline Mining \& quarrying & 57 \\
\hline TOTAL SMEs & 496,458 \\
\hline
\end{tabular}

Source: SME Corp. (2014).

Table 2 shows the number of micro enterprises divided into several sectors which are manufacturing, service, agriculture, construction and mining and quarrying (SME Corp, 2014). The highest establishment of micro enterprises is in the service sector with 462,420 enterprises. It follows by manufacturing with 21,619 establishments, construction with 8,587 establishments, agriculture with 3,775 micro enterprises and mining and quarrying with only 57

\section{Volume 6 Issue 7, July 2017 www.ijsr.net}




\section{International Journal of Science and Research (IJSR) \\ ISSN (Online): 2319-7064}

Index Copernicus Value (2015): 78.96 | Impact Factor (2015): 6.391

enterprises. Thus, the population for this study is the micro enterprises which established in service sector.

Apart from that, this study uses three sampling designs. The first one is cluster sampling. It is used when a heterogeneous group is to be studied at once (Uma \& Roger, 2013). SMEs have been clustered into micro enterprises, then, clustered into service sector and lastly, it had been clustered into states. The second sampling design used is simple random sampling. The simple random sampling is defined as every element in the population has equal chance in order to be selected to become subject (Uma \& Roger, 2013). This study distributes questionnaires to the chosen states, which are WP Kuala Lumpur, Selangor, Kedah and Kelantan. The total number of questionnaires distributed was 200, which divided equally, 50 sets per state, to the states so that every enterprise in the chosen states has the equal chance to be the subject for this study. The third sampling design is convenience sampling. Convenience sampling is the nonprobability design, which is not generalizable at all, is used at times to obtain some rapid information from the respondents to know the overview of the case. This sampling method had been used when the pilot testing is performed in WP Kuala Lumpur, Selangor, Kedah and Kelantan.

\subsection{Questionnaire instrument}

This study adopts questionnaires of Mamorena and Olumide (2014), Peninnah (2014), Mbugua et al. (2014), Kinyua (2014), Nyagah (2013) and $\mathrm{Wu}$ (2009). This questionnaire has been developed in two languages which are Malay and English language. In addition, the questionnaire is in closedended questions, which are required respondents to select the answer from the options given by researchers. The questionnaire uses in this study consists of three parts.

Firstly, Part A of the questionnaire is the demographic (D) section that relates to respondent's personal and their enterprise details. A total of six questions is in this part. There will be some choices of answers regarding the question that correlated with their enterprise. Respondents are required to tick the accurate answer that is most connected to the enterprise in the box given. This information includes their highest level of education, enterprise activity, years of enterprise establishment and sources of initial capital. As well as number of employee(s) and total annual sales (RM), those indicate the size of the enterprise.

Secondly, Part B of the questionnaire indicates financial and non-financial performances of SMEs as the dependent variable. This study measures financial performance in term of enterprise profit, sales and cash flow which have three questions for each indicator of measurement. Meanwhile, measurement for non-financial performance is based on employees, customers and product development which have three questions also for each indicator. All answers in Part B are in five-point Likert Scale ranging from 1 to 5:-

1) Strongly Disagree $(\mathrm{SD})=1$

2) Disagree $(D)=2$

3) Neither Disagrees Nor Agree $(\mathrm{N})=3$

4) Agree (A) = 4

5) Strongly Agree $(\mathrm{SA})=5$
Respondents need to circle the appropriate number based on the questions given.

\section{Findings}

\subsection{Demographic of respondents}

Below in Table 3 are the demographic result of respondent. It shows that most of the respondents which are 91 (45.5\%) completed secondary school as their highest level of education. In term of business activities, restaurants are the highest business activity that has been involved by 31 $(15.5 \%)$ micro enterprises. $63(31.5 \%)$ respondents have established their enterprise within 2 to 4 years. Besides, most of the micro enterprises which are $53(26.5 \%)$ have only one full time employee. In term of annual sales, the majority of the micro enterprises which are $132(66 \%)$ generate annual sales less than RM50,000. To strengthen the business, 132 (66\%) micro enterprises were operated by using owners' personal saving without receiving any financial assistance in term of capital from other parties. Meanwhile, 30 (15\%) micro enterprises' owners were taking bank loan as their start-up capital. Whereas, other micro enterprises received initiatives from government agencies.

Table 3: Demographic result

\begin{tabular}{|c|c|c|c|}
\hline Items & Detail & Frequency & Percent \\
\hline \multirow{7}{*}{$\begin{array}{l}\text { Highest Level of } \\
\text { Education }\end{array}$} & None & 46 & 23.0 \\
\hline & Primary school & 18 & 9.0 \\
\hline & Secondary school & 91 & 45.5 \\
\hline & Diploma & 29 & 14.5 \\
\hline & Bachelor's degree & 11 & 5.5 \\
\hline & Master's degree & 3 & 1.5 \\
\hline & Doctoral degree & 2 & 1.0 \\
\hline \multirow{18}{*}{$\begin{array}{l}\text { Business } \\
\text { Activity }\end{array}$} & Restaurant & 31 & 15.5 \\
\hline & Healthcare/ Beauty care & 26 & 13.0 \\
\hline & \begin{tabular}{|l} 
Transportation \\
\end{tabular} & 7 & 3.5 \\
\hline & Accommodation & 6 & 3.0 \\
\hline & Education & 6 & 3.0 \\
\hline & Finance & 2 & 1.0 \\
\hline & Insurance & 3 & 1.5 \\
\hline & Clothing & 25 & 12.5 \\
\hline & Sports & 8 & 4.0 \\
\hline & Hardware & 16 & 8.0 \\
\hline & Gadget & 22 & 11.0 \\
\hline & Cyber café & 8 & 4.0 \\
\hline & Households & 3 & 1.5 \\
\hline & Accessories & 7 & 3.5 \\
\hline & Retail & 4 & 2.0 \\
\hline & Food \& Drinking & 11 & 5.5 \\
\hline & Workshop & 5 & 2.5 \\
\hline & Other services & 10 & 5.0 \\
\hline \multirow{5}{*}{$\begin{array}{c}\text { Years of } \\
\text { Enterprise } \\
\text { Establishment }\end{array}$} & Less than 2 years & 15 & 7.5 \\
\hline & $2-4$ years & 63 & 31.5 \\
\hline & $5-7$ years & 59 & 29.5 \\
\hline & 8-10 years & 27 & 13.5 \\
\hline & More than 10 years & 36 & 18.0 \\
\hline \multirow{6}{*}{$\begin{array}{c}\text { Number of Full } \\
\text { Time Employee(s) }\end{array}$} & 1 employee & 53 & 26.5 \\
\hline & 2 employees & 40 & 20.0 \\
\hline & 3 employees & 33 & 16.5 \\
\hline & 4 employees & 24 & 12.0 \\
\hline & 5 employees & 28 & 14.0 \\
\hline & More than 5 & 22 & 11.0 \\
\hline Total Annual & Less than RM50,000 & 132 & 66.0 \\
\hline
\end{tabular}

Volume 6 Issue 7, July 2017 www.ijsr.net

Licensed Under Creative Commons Attribution CC BY 


\section{International Journal of Science and Research (IJSR) \\ ISSN (Online): 2319-7064}

Index Copernicus Value (2015): 78.96 | Impact Factor (2015): 6.391

\begin{tabular}{|c|c|c|c|}
\hline \multirow{4}{*}{ Sales (RM) } & RM50,001-RM100,000 & 52 & 26.0 \\
\cline { 2 - 4 } & $\begin{array}{c}\text { RM100,001- } \\
\text { RM200,000 }\end{array}$ & 11 & 5.5 \\
\cline { 2 - 4 } & $\begin{array}{c}\text { RM200,001- } \\
\text { RM300,000 }\end{array}$ & 5 & 2.5 \\
\hline $\begin{array}{c}\text { Sources of Initial } \\
\text { Capital }\end{array}$ & Personal saving & 132 & 66.0 \\
\cline { 2 - 4 } & Bank loan & 30 & 15.0 \\
\cline { 2 - 4 } & MARA & 11 & 5.5 \\
\cline { 2 - 4 } & MIDA & 1 & 0.5 \\
\cline { 2 - 4 } & TEKUN & 4 & 2.0 \\
\cline { 2 - 4 } & Amanah Ikhtiar & 16 & 8.0 \\
\cline { 2 - 4 } & SME Corporation & 6 & 3.0 \\
\hline
\end{tabular}

\subsection{Financial and nonfinancial performance}

According to George (2005), the descriptive statistic is ways of summarizing large sets of numerical data. In addition, the descriptive statistic is used to describe the measurement of the data in a study (William, 2006). Therefore, this section explains the result of descriptive statistics analysis including minimum, maximum, mean, standard deviation, skewness and kurtosis.

Table 4: Descriptive Statistics Analysis

\begin{tabular}{|c|c|c|c|c|c|}
\hline \multicolumn{7}{|c|}{ Statistics } \\
\hline \multicolumn{7}{|c|}{$N$} & Max & Mean & Std. Dev. \\
\hline MFPP & 200 & 1.33 & 5.00 & 3.52 & 0.77 \\
\hline MFPS & 200 & 1.33 & 5.00 & 3.53 & 0.79 \\
\hline MFPC & 200 & 1.00 & 5.00 & 3.31 & 0.74 \\
\hline MNPE & 200 & 2.00 & 5.00 & 4.11 & 0.61 \\
\hline MNPC & 200 & 1.00 & 5.00 & 3.74 & 0.71 \\
\hline MNPP & 200 & 1.67 & 5.00 & 3.74 & 0.66 \\
\hline
\end{tabular}

Where: MFPP=Mean of Financial Performance for Profit, MFPS=Mean of Financial Performance for Sales, MFPC=Mean of Financial Performance for Cash flow, MNPE=Mean of Nonfinancial Performance for Employees, MNPC=Mean of Nonfinancial Performance for Customer, MNPP=Mean of Nonfinancial Performance for Product Development.

Table 4 represents the result of financial and nonfinancial performance of the SMEs. Overall, the result shows that the mean values for all variables of financial performance are more than 3 (neither disagree nor agree). Sales with the highest mean value of 3.53 (agree) as the range value between 1.33 (strongly disagree) and 5 (strongly agree). Followed by, profit with the mean value of 3.52 (agree) as the range value 1.33 (strongly disagree) to 5 (strongly agree). And the mean value of cash flow is 3.31 (neither disagree nor agree) as the range value of 1 (strongly disagree) to 5 (strongly agree). Therefore, it can be concluded that most of the respondents in WP Kuala Lumpur, Selangor, Kedah and Kelantan agree that their micro enterprises have good financial performance. It might be due to their strategic enterprise location that could attract lots of customers to buy their products/services, directly causing to their high sales amount. Subsequently, it contributes to their high profit as well. However, cash flow indicator seems to be low compared to others due to lack of management skill and ability among them in managing their cash in and out (Moya, 2015).

Secondly, for non-financial performance, the result shows that the mean values for overall non-financial performance

elements are more than 3 (neither disagree nor agree). Employees with the highest mean value of 4.11 (agree) as the range value 2 (disagree) to 5 (strongly agree). Meanwhile, both customer and product development have the same mean value of 3.74 (agree) and the maximum score of 5 (strongly agree). However, the minimum score for the customer is 1 (strongly disagree) and product development is 1.67 (disagree) correspondingly. Therefore, it can be concluded that the majority of respondents in those four states agree that their enterprises have good non-financial performance.

\section{Conclusion}

The objective of this study is to measure the level of performance of micro enterprises in Malaysia. It can be measured by financial and non-financial performance of a enterprise. Most of the micro enterprises in Malaysia have a good financial and non-financial performance during their operating period.

This study may be beneficial to any enterprises in the market, especially in the micro. This is because the manager can know the crucial elements in improving the enterprise' performance from time to time. For example, the manager can increase the enterprise capital in order to improve the product's/service's quality, so that so that the manager and enterprises can get beneficial from profit and turnaround capital or increase more capital indirectly, the revenues and sales of the enterprise will be increased and it shows that the enterprise' performance has improved. Secondly, this study may be beneficial to any enterprise in any sectors, especially in the service sector. This is because this study was more focus on the service sector rather than others. The enterprises in the service sector can apply this study in their operations in order to improve the performance of their enterprise. The service sector is the highest number of establishments of SMEs in total (SME Corp, 2014). Thus, if every enterprise in service sector applies this study, the performance of this sector will be enhanced and indirectly will affect the performance of total SMEs since this sector is the highest number of establishments of SMEs.

This study also may be beneficial to the economy in Malaysia. SMEs will affect the long-term development of Malaysia (Muhamad Wasim \& Muahamad Khalique, 2014). Directly, the performance of SMEs will affect the GDP growth in Malaysia. According to SMEs Annual Report (2013), the statistics of SMEs GDP growth have been increased from the year 2012 to 2013 by $0.3 \%$. SMEs also can increase the employment rate and the standard of living of employers and employees (Mbugua et al., 2014). Therefore, access to capital, government regulation, managerial characteristics and availability of facilities are useful to SMEs in Malaysia.

There are some limitations that have been faced by researchers in conducting this study. Firstly, the limitation is in term of research sources, including articles, journals and statistics. There is still lack of researches have been conducted in Malaysia that using micro enterprises as their sample. However, many studies were made outside this

\section{Volume 6 Issue 7, July 2017 www.ijsr.net}




\section{International Journal of Science and Research (IJSR) \\ ISSN (Online): 2319-7064}

Index Copernicus Value (2015): 78.96 | Impact Factor (2015): 6.391

country (Munoz, Welsh, Chan \& Raven, 2014). Therefore, researchers have difficulties in finding the journals, articles and news in Malaysia related to the subject of this study.

Besides that, there are no recent statistics for the population of the sample produced by the responsible bodies. The latest one is passed four years ago, which is in 2011 published by the Department of Statistic, Malaysia. Unfortunately, those statistics comprise all sizes of enterprises such as micro, small and medium. Thus, it makes difficult for researchers to get the specific statistic for micro enterprises only within these four states of WP Kuala Lumpur, Selangor, Kedah and Kelantan. Consequently, the entire sample in those four selected states cannot be generalized in this study.

\section{References}

[1] Annastazia, M. \& Robert, G. M. (2014). Socio-Cultural Factors and Financial Performance among Women Small and Medium Enterprises in Tanzania. European Journal of Business and Management, 6(32), 153-163.

[2] Awa, H. O., Ojiabo, O. U. \& Emecheta, B. C. (2012). Integrating TAM and TOE frameworks and expanding their characteristic constructs for e-commerce adoption by SMEs. Proceedings of Informing Science \& IT Education Conference (InSITE 2012).

[3] Canan, S., Hidayet, K., Yasemen, K., Perihan, T. \& Hakan, M. K. (2008). Can SMEs in developing

countries resist crisis? An analysis on Turkish and Albanian cases. Proceeding of $1^{\text {st }}$ International Conference on Balkans Studies (ICBS 2008).

[4] Che Zuriana, M. J. \& Rapiah, M. (2011). Performance Measurement System (PMS) In Small Medium Enterprises (SMES): A Practical Modified Framework. World Journal of Social Sciences. 1(3), 200-212.

[5] Christopher, D. I. \& David, F. L. (2003). Coming Up Short on Non-financial Performance Measurement. Retrieved 20 $0^{\text {th }} \quad$ June 2017: https://hbr.org/2003/11/coming-up-short-on-nonfinancial

[6] Daniel, K. K. \& Okibo, W. B. (2014). Competitive Strategies and the Non Financial Performance of Micro Enterprises in Kenya (A Survey of Industrial Knitting Micro Enterprises in Kiambu County). International Journal of Management and Commerce Innovations, 2(2), 160-186.

[7] Dikolli, S. (2010). Discussion of Nonfinancial Performance Measures and Physician Compensation. Journal of Management Accounting Research, 22, 5764.

[8] Farhan, S. F. \& Nur Naha A. M. (2011). The Critical Success Factors of Performance Measurement for Malaysian SME's in Manufacturing Sectors: A Proposed Framework. Proceeding of $2^{\text {nd }}$ International Conference on Business and Economic

Research (ICBER2011).

[9] George, B. (2005). Descriptive statistics. Retrieved $2^{\text {th }}$ June 2017: http://webspace.ship.edu/cgboer/

[10] Khrystyna K., Melina L. M. \& Rita R. (2010). Micro, Small, and Medium Enterprises around the World: How many are there, and what affects the count? Retrieved 31
June
http://www.ifc.org./wps/wcm/connect/MSME-

[11] Kinyua, J. (2014). Effect of access to micro financing on financial performance of small and medium sized enterprises in Gikomba market, Nairobi county. Unpublished Doctorate of Philosophy thesis, University of Nairobi.

[12] Krishna, M., Annie T., Caroline C., Chang, S. W., Jonathan T. Y. P. \& Tan. K. L. (2012). A Study on Factors Affecting the Performance of SMEs in Malaysia. International Journal of Academic Research in Business and Social Sciences, 2(4), 224-239.

[13] Mohd Amy, A. M. H, Chee, H. H. \& Mohamad, I. A. (2013). The Financial and Non- Financial Performance Indicators of Paddy Farmers' Organizations in Kedah. World Review of Business Research. 3(1), 80-102.

[14] Majidah, H. \& Grace, M. C. (2011). Influential Organizational Capabilities for SMEs' Export Performance: An Exploratory Study.

[15] Mashenene, R. G., Macha, J. G. L. \& Donge, L. (2014). Socio-Cultural Determinants of Entrepreneurial Capabilities among the Chagga and Sukuma Small and Medium Enterprises in Tanzania. Journal of Economics and Sustainable Development, 5(17), 90 103.

[16] Mamorena, L. M. \& Olumide, H. B. (2014). NonFinancial Performance Measures in Small Medium Enterprises' Supply Chain Management. Economics Journal, 5(3), 247-257.

[17] Mbugua, S. K., Agnes, N. \& Ondabu, I. T. (2014). Factors Affecting the Performance of Small and Micro Enterprises in Limuru Town Market of Kiambu Country, Kenya. International Journal of Science and Research Publications, 4(12), 2250-3153.

[18] Monge-González, R. \& Torres-Carballo, F. (2015). The Dynamics of Entrepreneurship in Costa Rica. An Analysis of Firm Entry, Exit, and Growth Rates. InterAmerican Development Bank Discussion Paper.

[19] Moya. (2015). What Causes Small Businesses to Fail? Retrieved 20th June 2017: http://www.moyak.com/papers/small-business-failure.

[20] Muhammad Wasim J. K. \& Muhamad Khalique. (2014). An Overview of Small and Medium Enterprises in Malaysia and Pakistan: Past, Present and Future Scenario. Business and Management Horizons, 2(2), 3849.

[21] Munoz, J. M., Welsh, D. H., Chan, S. H. \& Raven, P. V. (2014). Microenterprises in Malaysia: a preliminary study of the factors for management success. International Entrepreneurship and Management Journal, 1-22.

[22] Nurazree, M. \& Mohd Faiz, H. (2013). TQM and Malaysian SMEs Performance: The Mediating Roles of Organization Learning. Procedia-Social and Behavioral Science, 130, 216-225.

[23] Nyanga, T., Zirima, H., Mupani, H., Chifamba, E. \& Mashavira, N. (2012). Survival of the Vulnerable: Strategies Employed by Small to Medium Enterprises in Zimbabwe to Survive an Economic Crisis'. Journal of Sustainable Development in Africa, 15(6), 142-152.

[24] Nyangoma, P. S. (2012). Credit Terms, Access to Finance and Financial Performance of SMEs in

\section{Volume 6 Issue 7, July 2017 www.ijsr.net}


Kampala. Unpublished Master thesis, Makarere University.

[25]Peninnah, M. M. (2014). An Investigation into the Factors Influencing Sustainability of Women Owned SMEs in Kenya: A Case of Machakos Country. Unpublished Master thesis, University Of Nairobi.

[26] SME Corp. (2014). SMEs Annual Report 2014/2015. Retrieved $30 \quad$ December 2015: http://www.smecorp.gov.my/index.php/en/resources/20 15-12-21-11-07-06/sme- annual report/book/7-annualreport-2014/2-annual-report

[27] Tundui, C. S. \& Tundui, H. (2012). Survival, Growth Strategies and Performance of Women Owned Micro and Small Businesses in Tanzania. International Journal of Business and Management, 7(8), 143-155.

[28] Uma, S. \& Roger, B. (2013). Research Methods for Business: A Skill-Building Approach. Sixth Edition. United Kingdom: John Wiley \& Sons Ltd.

[29] William, M. K. (2006). Descriptive Statistics. Retrieved $20^{\text {th }}$ November 2015: http://www.socialresearchmethod

[30] Wong, K. L., Kuek, T. Y. \& Ong, S. F. (2013). Strategic Planning and Business Performance: A Study of SMEs in Malaysia. Proceedings of $3^{\text {rd }}$ Asia-Pacific Business Research Conference (APBRC 2103).

[31]Wu, D. (2009). Measuring Performance in Small and Medium Enterprises in the Information Communication Technology Industries. Unpublished Doctorate of Philosophy thesis, Royal Melbourne Institute of Technology (RMIT) University.

\section{Author Profile}

Nurul Nadiah Ahmad received the Degree in Accounting from International Islamic University Malaysia and Master in Accounting from Universiti Teknologi Mara, Malaysia. Her research area is in corporate governance, accounting education, financial reporting and green sustainability. 